Research Article

\title{
THE EFFECT OF SINGLE- AND REPEATED- EXCESSIVE SWIMMING EXERCISE ON KIDNEY HISTOPATHOLOGY OF MALE RATS WISTAR STRAIN (Rattus norvegicus)
}

\author{
Wenni Juniarni Tripani' ${ }^{1}$, Muhammad In'am Ilmiawan², Willy Handoko ${ }^{3}$ \\ 1) Faculty of Medicine, Tanjungpura University Pontianak, West Borneo. \\ 2) Department of Biology and Pathobiology, Faculty of Medicine, Tanjungpura University Pontianak, West Borneo. \\ 3) Department of Physiology, Faculty of Medicine, Tanjungpura University Pontianak, West Borneo.
}

*Corresponding author: wjuniarni@gmail.com

\begin{abstract}
Background: Physical exercise aims to improve or maintain physical fitness. However, excessive physical exercise may cause increase of oxidative stress which leads to cellular injury, including in the proximal tubules of kidney. This research aims to find out the effect of single- and repeatedexcessive swimming exercise to the kidney histopathology of male wistar rats (Rattus norvegicus). Methods: This research was an experimental study with complete random and post test only control group design. Twenty seven male wistar rats were divided into three treatment groups: control group, single- excessive swimming exercise group (45 minutes for one day), and repeatedexcessive swimming exercise group (45 minutes/day for seven days). In the end of the treatment, the kidney of the rats were taken to be analyzed by using hematoxylin-eosin stain. The mean of proximal tubules injury of kidneys were counted by two observers using blinded method. Data were analyzed by using one way anova test. Result: The analysis showed there was a significant difference in the mean percentage of proximal tubules injury between control group and single swimming group as well as the repeated swimming group (Anova $p=0,000$ ), also there was significant difference between the treatment groups $(p=0,020)$. The highest average of proximal tubules injury was in the single swimming group. Conclusion: Single- and repeated- excessive swimming exercise causes the proximal tubules injury of kidney.
\end{abstract}

Keywords: Single- and repeated- excessive swimming exercise, kidney histopathology, male wistar strain rats. 


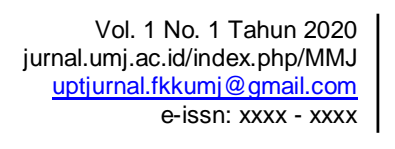

\section{INTRODUCTION}

Physical exercise is a planned, structured, repeated physical activity of body in order to improve physical fitness (1). However, an excessive physical exercise could increases the production of free radicals as well as increases endogenous antioxidant (2).

Approximately one-third of young English athletes have experienced excessive physical exercise (3). It was reported that $35 \%$ of adolescent swimmers had been experienced excessive exercise at least once. $5 \%$ to $30 \%$ of swimmers over a season and in $15 \%$ of British elite athletes ever experienced excessive exercise (4).

Excessive physical exercise causes oxidative stress which could damage body's cell including kidney (5). Nayanatara et al reported that 45 minutes swimming stress daily for 7 days increases the lipid peroxidation of liver, kidney, adrenal gland and cerebral cortex (6). Kidney is an organ contains 1 - 1,4 million unit of nephrons. Nephron composed of a glomerulus and a tubule both play important role in maintaining body salt, fluid balance and waste excretion. The function of kidney is to keep the stabilization of cell environment to do many activities. The kidney function can be disrupted due to damage to its components (7).

Olivia $\mathrm{N}$ stated that a group of swimming animal without vitamin $\mathrm{E}$ consumption showed the widest damage in kidney proximal tubulus (8). Lin et al reported that the animal group with staged treadmill physical exercise up to exhausted found damage in tubulus including degeneration of tubular epithelial cells and

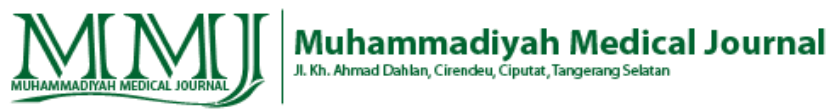

apoptosis (9). Excessive physical exercise could also cause rhabdomyolysis or Exerciseinduced rhabdomyolysis (exRML), it is a damage on the skeletal muscle with the increase of creatin kinase (CK) or mioglobin $(\mathrm{Mb})$ which could disrupt the kidney function (10).

Although many studies have reported that exercise could cause cell damage due to free radicals, exercise could also increase endogenous antixodant capacity and increase oxidative damage repairing enzymes (2). It has been reported that exercise intensity and duration of exercise can affect the level of free radical damage. Acute exercise causes more oxidative stress in the liver tissue compared to repeated exercise $(11,12)$.

Until now, the effects of different types of excessive exercise on the kidney are unknown. Therefore this study was conducted with the aim of finding out the effect of single and repeated excessive exercise on the kidney.

\section{METHODS}

\section{Animals and Acclimatization}

Male wistar strain rats (Rattus norvegicus) age $2-3$ months $(180-220 \mathrm{~g})$ were acclimatized for 3 days and were fed with normal pellet diet and water ad libitum throughout the experimental period.

\section{Research Design}

This research was a complete random experimental design post-test only group control. Twenty seven male wistar rats were randomly divided into three treatment groups consisting of nine rats in each as follows: 
Vol. 1 No. 1 Tahun 2020

jurnal.umj.ac.id/index.php/MMJ

$\frac{\text { uptjurnal.fkkumj@gmail.com }}{\text { e-issn: } x x x x-x x x x}$

- Group C: Control

- Group P1: Single excessive swimming exercise 45 minutes for one day

- Group P2: Repeated excessive swimming exercise 45 minutes/day for seven days

All the animals were sacrificed at the end of the each treatments. The kidneys were washed in $0.9 \% \mathrm{NaCl}$ for removal of attached blood and were fixed in $10 \%$ buffered formalin for histopathological analysis.

\section{Research Setting}

The setting of the research was in animal laboratory of Medical Faculty of Universitas Tanjungpura (the animal care and treatment), Non Microscopic Laboratory of Medical Faculty of Universitas Tanjungpura (Surgery and Organ Taking), Anatomy Pathology Laboratory of Dr. Soedarso General Hospital (Histopathology slides and haematoxylin eosin staining) and Microscopic Laboratory of Medical Faculty of Universitas Tanjungpura (Histopathology analysis).

\section{Histopathology analysis}

The Haematoxylin eosin slides examination performed through digital camera from 10 fields (40x objective lens) microscope. Observations were made on 100 proximal tubules and the mean of renal proximal tubule damage is calculated using the formula: Number of abnormal proximal tubules per 100 proximal tubules.

\section{Data Analysis}

The Anova test and The Post Hoc Least Square Difference (LSD) test were performed using Statistical Product and Service Solutions (SPSS) 22 for windows.

\section{ETHICAL CLEARANCE}

The study was approved by the Health Research Ethics Commission of the Medical Faculty of Tanjungpura University (7637 / UN22.9 / DT / 2016).

\section{RESULTS}

\section{Histopathology analysis}

Histological picture of kidney tissue in group $\mathrm{C}$, group $\mathrm{P} 1$ and group $\mathrm{P} 2$ can be seen in Figure 1, Figure 2 and Figure 3.

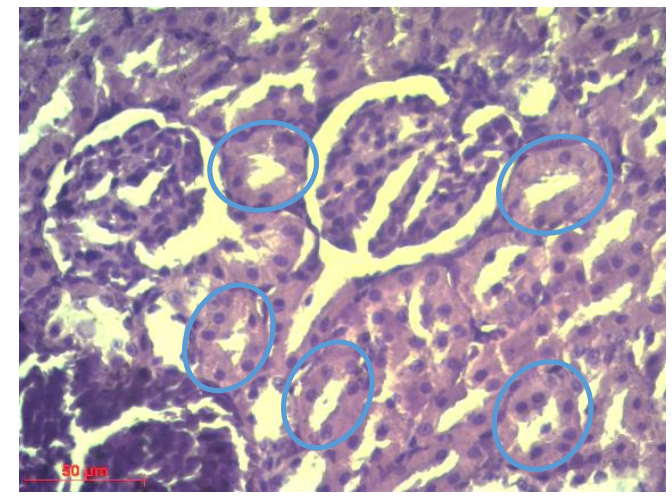

Picture 1. Histopathological picture of the control group's kidney. There is a picture of the normal proximal renal tubules (blue circle). HE coloring, objective 40x. 
Vol. 1 No. 1 Tahun 2020

jurnal.umj.ac.id/index.php/MMJ

$\frac{\text { uptjurnal.fkkumj@gmail.com }}{\text { e-issn: } x x x x-x x x x}$

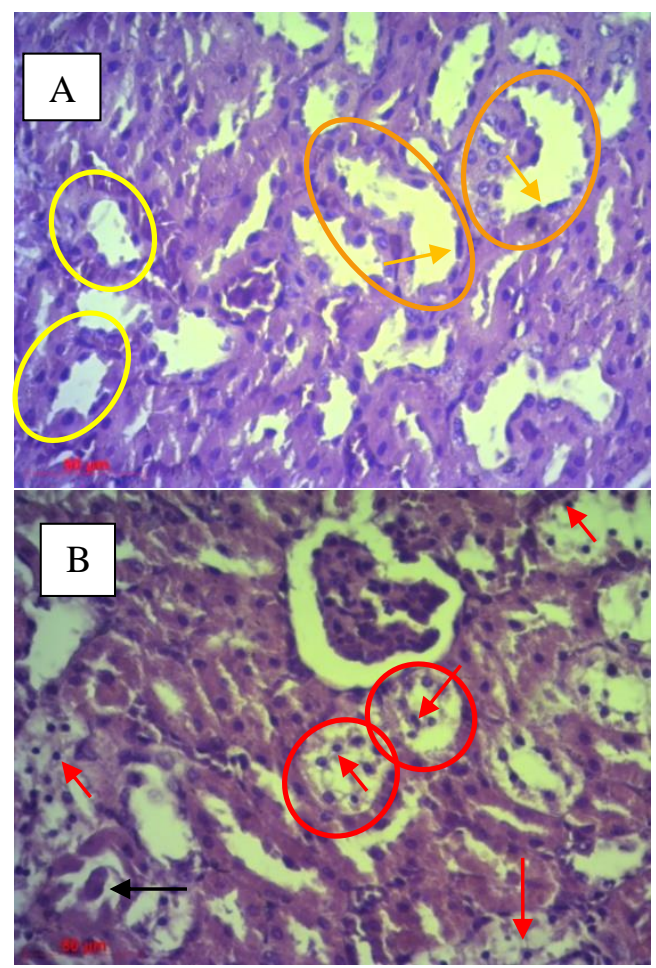

Picture 2. Renal histopathology features of a single swim-load exercisegroup. There is a picture of damage in the form of loss of the brush border (yellow circle) and accompanied by tubular dilation (orange circle) (figure A). Damage is also in the form of tubular epithelial cell necrosis (red circle) which is characterized by a picnotic nucleus (red arrow) and intratubular cast (black arrow) discovery (figure B). HE coloring, objective 40x.
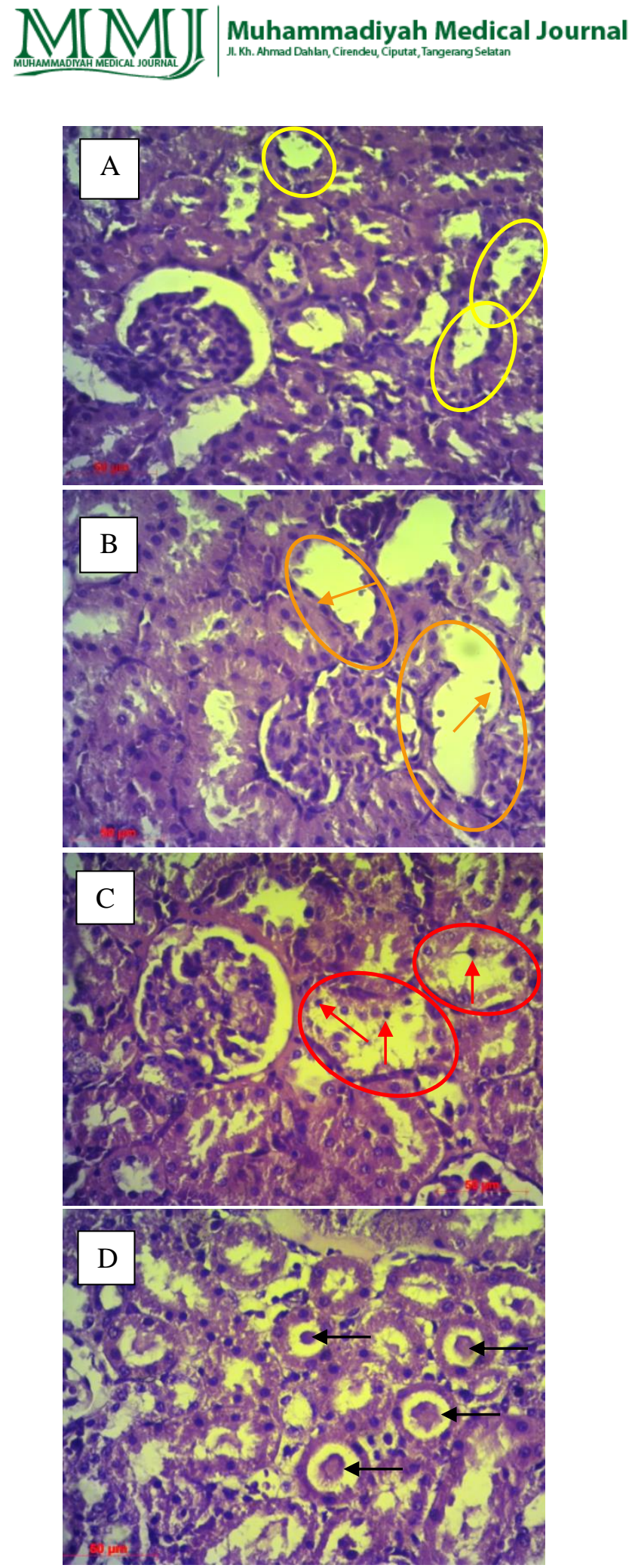

Picture 3. Histopathological features of the kidney repeated exercise-swimming load group. There is a picture of proximal tubular damage in the form of loss of the brush border (yellow circle) (figure A), loss of brush border accompanied by tubular dilation (orange circle) (picture B). Damage is also in the form of tubular epithelial cell necrosis (red circle) which is 


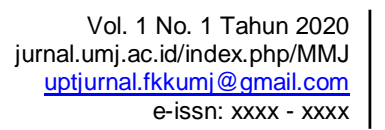

characterized by a picnotic nucleus (red arrow). An intratubular cast was found in the proximal tubule (black arrow) (figure D). HE coloring, objective 40x.

\section{Mean Proportion of Kidney Tubule Damage Percentage Results}

The results of the mean percentage of proximal tubular damage can be seen in Figure 4. The analysis results obtained data for each group normally distributed and homogeneous variance. Anova one-way test results showed that there were significant differences between groups $(p=0.00)$ and continued by Post-Hoc LSD test.

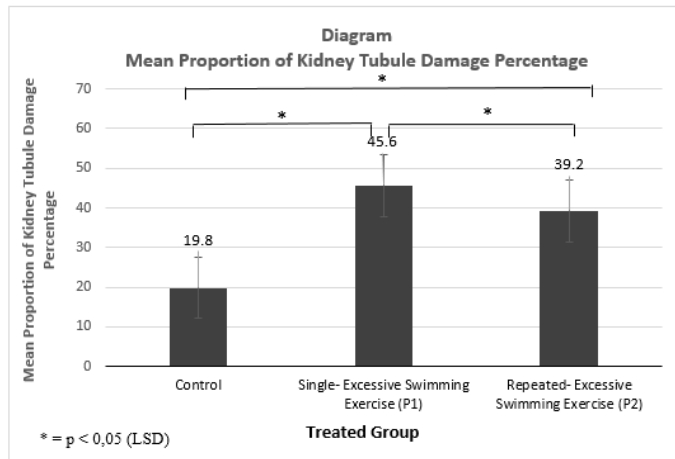

Picture 4. Mean Proportion of Kidney Tubule Damage Percentage Results

From the Mean Proportion of Kidney Tubule Damage Percentage Results on the picture 4 . The mean percentage of over loaded swimming - exercise group is the highest. The repeated swimming exercise has lower percentage of damage than over loaded swimming - exercise group (LSD $p=0,020$ ). The lowest percentage of damage is found in the control group and the significant difference from over single swimming exercise $(\mathrm{p}=0.00)$ or The repeated swimming exercise group $(\mathrm{p}=0.00)$.

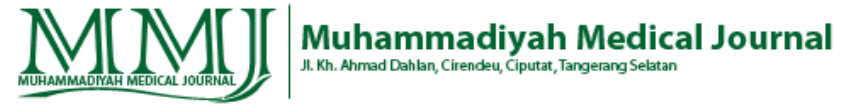

\section{The Percentage of Damage on the Tubule}

The result of percentage on the tubule damage based on the histology can be seen in the Table 1.

Tabel 1. The percentage of Kidney Tubule Damage Percentage

\begin{tabular}{|c|c|c|c|}
\hline Group & $\mathbf{K}$ & P1 & $\mathbf{P 2}$ \\
\hline Brush border lost & $19,25 \%$ & $35,60 \%$ & $29,40 \%$ \\
\hline Intratubular cast & $0,00 \%$ & $0,30 \%$ & $1,10 \%$ \\
\hline $\begin{array}{l}\text { Sitoplasma } \\
\text { Vacuolization }\end{array}$ & $0,00 \%$ & $0,00 \%$ & $0,20 \%$ \\
\hline $\begin{array}{l}\text { Proximal tubular } \\
\text { necrosis }\end{array}$ & $0,00 \%$ & $3,00 \%$ & $2,05 \%$ \\
\hline $\begin{array}{l}\text { Tubule dilatation } \\
\text { and brush border } \\
\text { lost }\end{array}$ & $0,65 \%$ & $6,70 \%$ & $6,50 \%$ \\
\hline
\end{tabular}

Based on the table 1, it can be seen that the most type of damage found in the control group forms in the lost of brush border or followed by Nekrosis proximal tubule.

\section{DISCUSSION}

Physical exercise has a goal to increase or maintain the physical fitness (1). However over physical exercise could bring harmful effect to the body because the production of free radicals $(4,13)$. Research of Thirumalai reported that intensive swimming exercise could raise reactive oxygen species (ROS) in the muscle (14). 


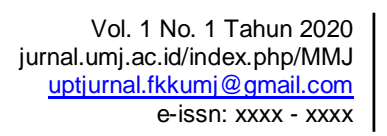

The treated animals were given swimming - exercise load for 45 minutes. The swimming exercise was given as a stressor which could increase protein degradation in the muscle and increase glukokortikoid level in the plasma as the stress respond happen in the body (15). Hu reported the increase of glukokortikoid level in the plasma was found after 45 minutes exercise (11).

This study has found that the kidney damage level higher in the both treatment groups the single exercise group and in the repetitive exercise group than the control group. The damage was generally in the form of loss of the brush border. The mechanism accounting for the lost of brush border on proximal tubule could be the impaired membrane integrity and membrane polarity due to ischemia and oxidative stress. The intratubular cast can be formed by damage of the tubular cells due to ischemia condition (16). The damage on kidney proximal tubule could be caused by the ischemia condition during hard physical exercise $(17,18)$. The renal vasoconstriction is augmented during exercise at moderate and maximal intensities and subsequently decreases oxygen delivery to the tubules (19). The tubular epithelial cells are sensitive to ischemia. In time, the injured tubular cells detach from the basement membranes (16). Another mechanism of cast forming is the rhabdomyolysis increases serum myoglobin and in a state of hypovolemia and decreased urine $\mathrm{pH}$, myoglobin can precipitate with Tammhorsfall protein. The casts can cause tubular obstruction $(20,21)$.

The state of ischemia can cause a failure of oxidative phosphorylation which will reduce ATP production. Decreasing the amount of ATP will cause the accumulation of intracellular $\mathrm{Na}^{+}$due to failure of the $\mathrm{Na}^{+} \mathrm{K}^{+}$-ATPase pump in maintaining ion balance, causing cell swelling. If the state of ischemia is prolonged, irreversible cell damage will occur (16).

Acute kidney damage due to exercise also reflects renal ischemia caused by rabdomiolysis, ie destruction of skeletal muscle fibers in the form of myocyte lysis results in releasing of muscle fiber into extracellular fluid and blood. As a result, free myoglobin in plasma increases, so that large amounts of myoglobin are filtered by the kidneys. Myoglobin can be nephrotoxic directly mediated by free radicals and also interfere with even inhibit the kidney filtration system (20,21). Myoglobin accumulation can also form ROS and trigger lipid peroxidation which damages cell membranes and blood vessels in the kidneys $(10,22)$.

Kidney proximal tubule damage can also be caused by oxidative stress that occurs during strenuous physical exercise. Acute physical exercise conducted intensively causes an imbalance between ROS and the body's antioxidant system which can be a potential source of oxidative stress $(17,23)$. Di Meo reported that strenuous physical exercise decrease blood flow to the kidneys and will return to normal (24). Return of $\mathrm{O}_{2}$ supply to the kidneys after an ischemic condition causes a reperfusion of ischemic lesions and increase ROS production. The increased ROS is caused by mitochondrial dysfunction that occurs in the proximal tubule during the state of ischemia. Increased ROS causes lipid peroxidation of the proximal tubular membrane (16). 


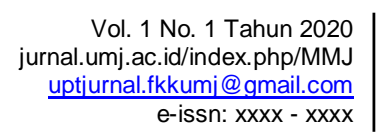

The mean percentage of renal proximal tubule damage in the single excessive swimming group (P1) was significantly higher than in the repetitive excessive swimming group (P2). This is likely due to kidney lipid peroxidation is higher in the Group P1 than Group P2. Podhorska's reported an increased incidence of apoptosis in distal tubular cells and collecting ducts in rat kidneys after acute exercise compared to the 8-week exercise group (25).

$\mathrm{Li}$ reported that with the increase of exercise intensity, the SOD (Superoxide Dismutase) activity in the rats decreased gradually, whereas the MDA (malondialdehyde) and NO (nitric oxide) levels gradually increased (26). Prasmadhan showed that giving maximum physical activity in swimming for 30-60 minutes in one time significantly decreases the total blood antioxidant activity when compared to the control group (27). Conditions of oxidative stress and free radicals will cause lipid peroxidation of cell membranes (28).

The mean percentage of renal proximal tubule damage in the repetitive excessive swimming group was significantly higher than in the control group. This result was similar to that reported by Nayanatara et al which showed that a 45-minute physical exercise swimming repeated for seven days led to an increase in lipid peroxidation production in the liver, kidneys, adrenal glands and cerebral cortex significantly, which shows the occurrence of oxidative stress in the liver, kidney, adrenal gland, and cerebral cortex (6). However, the mean percentage of proximal tubule damage in the excessive repetitive swimming load group was lower than the single excessive swim load group. This might be caused by an increase in the activity of antioxidant enzymes after repeated physical exercises (29).

Nagaraja reported that kidney weight calculated per $100 \mathrm{~g}$ of rat body weight increased significantly in the daily swimming group $(0.347 \pm 0.012)$, seven days $(0.344 \pm$ $0.007)$, and fifteen days $(0.334 \pm 0.005)$ compared to the control group (0.310 \pm 0.003). But the highest increase was in the daily swimming group compared to other groups. During swimming treatment, there is an increase in workload in the kidneys and changes in homeostatic mechanisms such as increased cardiac output and blood pressure during stress. This can cause increase in kidney weight. If the stress period was prolonged, a gradual recovery occurs back to normal (30). Animal response decreased to prolonged stress through habituation or adaptation. Research conducted by Moningka also found that repeated voluntary wheel running for 6 weeks could increase endothelial nitric oxide synthase (eNOS) and extracellular superoxide dismutase (EC SOD) (31). The increased activity of antioxidant enzymes is caused by repeated ROS exposure which could cause adaptation of the mitochondria of the proximal tubule of the kidney in repeated swimming exercises, but the mechanism of adaptation is still unknown (30). An increase in the antioxidant enzymes will inhibit the of lipid peroxidation in the proximal tubules so that the tubules proximal suffered less damage in the load repeated swimming-exercise group (32).

Saad RA's showed that regular swimming exercise in 11 consecutive weeks 
significantly decreases serum urea, creatinine and TNF $\alpha$ levels, as well as a significant decrease in kidney weight compared to the control group with ischemia. In addition, the levels of kidney tissue malondialdehyde (MDA) decreased, while the activity of catalase and NOS increased than the control group (33).

Histological changes in renal proximal tubule damage also occurred in the control group. This is thought to be influenced by stress that occurs in experimental animals when performed routine procedures in the laboratory and the influence of environmental conditions. According to Balcombe,noninvasive laboratory procedures such as handling, lifting, and when cleaning or moving cages of experimental animals can potentially significantly change physiological parameters related to stress such as corticosterone concentration, glucose, prolactin, heart rate, blood pressure, and behavior in experimental animals (34).

Environmental conditions for animals taking care both the condition of the taking care room and laboratory animal facilities are the limitations in this study (35). Acute stress and intensive physiological stressors can cause endocrine changes in the form of increased epinephrine in plasma which will trigger an increase in SGOT and urea levels in the blood. In addition, stress can induce injury to hepatocytes and degeneration of the glomerulus, Bowman's capsule, proximal tubules, distal tubules which cause abnormal filtration and reabsorption (36).

\section{CONCLUSION}

Based on the results of the study, it can be concluded that the excessive of single and

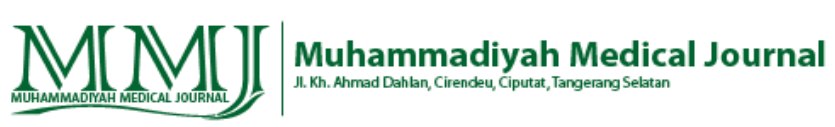

repeated exercise-swimming causes kidney proximal tubule damage. The highest percentage of proximal tubular damage was found in the group of single excessive swimming exercise group.

\section{CONFLICT OF INTEREST}

The authors state they have no conflict of interest, and no affiliation or connection to or with any entity or organization, which may raise a question of bias in discussion and conclusion of the manuscript.

\section{REFERENCES}

1. American College of Sports Medicine (Indianapolis Ind), Pescatello L, Deborah R, Paul D. ACSM's guidelines for exercise testing and prescription. Baltimore, MD: Wolters Kluwer, Lippincott Williams \& Wilkins; 2014.

2. Vina J, Olaso G, Arc-Chagnaud C, de la RA, Gomez-Cabrera M. Modulating oxidant levels to promote healthy ageing. Antioxid Redox Signal. 2020;

3. Matos N, Winsley R, Williams C. Prevalence of nonfunctional overreaching/overtraining in young English athletes. Med Sci Sport Exerc. 2011;43:1287-94.

4. Kreher JB, Schwartz JB. Overtraining Syndrome: A Practical Guide. Sports Health. 2012;4(2):128-38.

5. Fogarty M, Hughes C, Burke G, Brown J, Trinick T. Exercise-induced lipid peroxidation: implication for deoxyriibonucleic acid damage and systemic free radical generation. Env Mol Mutagen. 2011;52(35-42).

6. Nayanatara A, Nagaraja H, BK A. The Effect of Repeated Cold Water Swimming Exercise on Adaptive Changes in Body Weight in Older 
Rats. Thai J Physiol Sci. 2005;18(1):3-9.

7. Silverthorn D, Johnson B, Ober W, Garrison C, Silverthorn A. Human physiology: an integrated approach. 6th ed. Boston: Pearson Education; 2013. 890 p.

8. Olivia N. Pengaruh pemberian vitamin E terhadap gambaran histologis tubulus proksimal ginjal pada mencit betina dewasa (Mus musculus L) yang mendapat latihan fisik maksimal. J Ris Hesti Medan Akper Kesdam I/BB Medan. 2017;1(1):30.

9. Lin $\mathrm{X}$, Jiang $\mathrm{C}$, Luo $\mathrm{Z}, \mathrm{Qu} \mathrm{S}$. Protective effect of Erythropoietin on renal injury induced in rats by four weeks of exhaustive exercise. BMC Nephrol. 2013;14(1).

10. Kim J, Lee J, Kim S, Ryu HY, Cha KS, Sung DJ. Exercise-induced rhabdomyolysis mechanisms and prevention: A literature review. J Sport Heal Sci [Internet]. 2016;5(3):324-33. Available from: http://dx.doi.org/10.1016/j.jshs.2015. 01.012

11. Hu Y, Gursoy E, Cardounel A, Kalimi M. Biological effects of single and repeated swimming stress in male rats: beneficial effects of glucocorticoids. Endocrine. 2000;13(1):123-30.

12. El Abed K, Ammar A, Boukhris O, Trabelsi K, Masmoudi L, Bailey SJ, et al. Independent and Combined Effects of All-Out Sprint and Low-Intensity Continuous Exercise on Plasma Oxidative Stress Biomarkers in Trained Judokas. Front Physiol. 2019;10(July):1-10.

13. Bloomer R, Goldfarb A, Wideman L, McKenzie M, Consitt L. Effects of acute aerobic and anaerobic exercise on blood markers of oxidative stress. J Strength Cond Res. 2005;19(2):27685 .
14. Thirumalai T, Therasa SV, Elumalai EK, David E. Intense and exhaustive exercise induce oxidative stress in skeletal muscle. Asian Pacific J Trop Dis. 2011;1(1):63-6.

15. Sherwood L. Human physiology: from cells to systems. 9th edition. 9th ed. Boston, MA, USA: Cengage Learning; 2016. 1 p.

16. Kumar V, Abbas A, Aster J, Robbins $\mathrm{S}$, Editors. Robbins and Cotran pathologic basis of disease. 10th ed. Philadelphia: PA: Elsevier/Saunders; 2015. $1391 \mathrm{p}$.

17. Davies K, Quintanilha A, Brooks G, Packer L. Free radicals and tissue damage produced by exercise. Biochem Biophys Res Commun. 1982;107(4):1198-205.

18. Cooper C, Vollaard N, Choueiri T, Wilson M. Exercise, free radicals and oxidative stress. Biochem Soc Trans. 2002;30(2):280-5.

19. Kregel K. Augmented mesenteric and renal vasoconstriction during exercise in senescent Fischer 344 rats. J Appl Physiol Bethesda Md 1985. 1995;79(3):706-12.

20. Bosch X, Poch E, Grau J. Rhabdomyolysis and acute kidney injury. $\mathrm{N}$ Engl $\mathrm{J}$ Med. 2009;361(1):62-72.

21. Petejova N, Martinek A. Acute kidney injury due to rhabdomyolysis and renal replacement therapy: A critical review. Crit Care. 2014;18(3):1-8.

22. Zhang M. Rhabdomyolosis and its pathogenesis. World J Emerg Med. 2012;3(1):11.

23. Stanković M, Radovanović D. Oxidative stress and physical activity. Sportlogia. 2012;8(1):1-11.

24. Di Meo S, Venditti P. Mitochondria in exercise-induced oxidative stress. Biol Signals Recept. 2001;10(1-2):125-40.

25. Podhorska-Okołów M, Dziegiel P, 
Murawska-Ciałowicz E, Krajewska B, Ciesielska U, Jethon Z, et al. Exerciseinduced apoptosis in renal tubular cells of the rat. Folia Morphol. 2004;63(2):213-6.

26. Li XD, Sun GF, Zhu WB, Wang YH. Effects of high intensity exhaustive exercise on SOD, MDA, and NO levels in rats with knee osteoarthritis. Genet Mol Res. 2015;14(4):1236776.

27. Parasmadhan R, Wijayahadi N, Maksimal AF, Total AA. Terhadap Aktivitas Antioksidan Total Darah Tikus. 2015;4(4):1393-401.

28. Liu J, Yeo H, Overvik-Douki E, Hagen T, Doniger S, Chyu D, et al. Chronically and acutely exercised rats: biomarkers of oxidative stress and endogenous antioxidants. J Appl Physiol Bethesda Md 1985. 2000;89(1):21-8.

29. Teixeira De Lemos E, Oliveira J, Páscoa Pinheiro J, Reis F. Regular physical exercise as a strategy to improve antioxidant and antiinflammatory status: Benefits in type 2 diabetes mellitus. Oxid Med Cell Longev. 2012;

30. Nagaraja H, Jeganathan P. Forced swimming stress-induced changes in the physiological and biochemical parameters in albino rats. Indian $\mathrm{J}$ Physiol Pharmacol. 1999;43(1):53-9.

31. Moningka NC, Cunningham MW, Sterling M, West CA, Verlander JW, Croker BP, et al. Effects of voluntary wheel running on the kidney at baseline and after ischaemiareperfusion-induced acute kidney injury: A strain difference comparison. J Physiol. 2013;591(5):1313-24.

32. Ratliff BB, Abdulmahdi W, Pawar R, Wolin MS. Oxidant mechanisms in renal injury and disease. Antioxidants Redox Signal. 2016;25(3):119-46.
33. Saad RA. Long term exercise preconditioning protects against renal dysfunction after ischemia reperfusion injury in rat kidneys. J Am Sci. 2014;10(6):1.

34. Balcombe JP, Barnard ND, Sandusky C. Laboratory routines cause animal stress. Contemp Top Lab Anim Sci. 2004;43(6):42-51.

35. National Research Council. Guide for the care and use of laboratory animals. National Academies Press; 2010.

36. Kumar R, Kumar S, Ali M, Kumar A, Nath A, Lawrence K, et al. Impact of Stress on Histology and Biochemical Parameters of Liver and Kidney of Mice. Innov J Med Heal Sci. 2012;(June):63-6. 